\title{
Economic conditions and social cohesion: an analysis of French European Social Survey data
}

\section{Seongha $\mathrm{Cho}^{1}$}

Accepted: 18 September 2021 / Published online: 5 October 2021

(c) The Author(s), under exclusive licence to Springer Nature Limited 2021

\begin{abstract}
Concerns have been raised about weakening social cohesion in French society against the backdrop of economic slowdown over the last decade. To understand how economic conditions are associated with social cohesion, this study analyzes the correlations between individual and macroeconomic indicators and social cohesion attitudes as well as their cross-level interaction. The results from pooled OLS regressions with year fixed effects using French European Social Survey data (20082018) show that individual economic strain is associated with lower social trust and with higher egalitarian and anti-immigrant attitudes. Cross-level interaction results suggest that strained individuals can have stronger egalitarian and anti-immigrant propensities under a macroeconomic downturn. As a result, larger variations in public attitudes can occur, which could pose a risk to the value consensus and social order. The results of this study suggest potential negative consequences of microand macroeconomic hardship for various dimensions of social cohesion and suggest the need for a comprehensive policy strategy.
\end{abstract}

Keywords Social cohesion · Economic strain · Macroeconomic downturn · Pooled fixed effects OLS · European social survey

\section{Introduction}

Since the global financial crisis in 2008, Europe has experienced a prolonged period of economic slowdown. In France, this "decade of crisis" (Commissariat Général à l'Egalité des Territoires [CGET], 2018; Heyer and Timbeau, 2017) has been marked by low growth and high unemployment. The post-crisis decade's (2008-2017) average annual GDP growth rate was $0.79 \%$, a substantial decline compared to the rate in the pre-crisis period (1998-2007, 2.42\%) (The World Bank, 2020). Since the crisis,

Seongha Cho

bonjourpg7@gmail.com

1 College of Social Sciences, Department of Social Welfare, Seoul National University,

Gwanak-gu, Republic of Korea 
labor market conditions deteriorated, with a significant rise in the unemployed, underemployed, and unemployment halos (halo du chômage) (Heyer and Timbeau, 2017: 139). Although the European and French economies seemed to recover since 2017 (Szczepanski, 2019), the COVID-19 outbreak has again dealt a historic shock to the European economy.

Against the backdrop of economic slowdown, social indicators point to weakening social cohesion and deepening social fractures in France (Teyssedre and Le Bouler, 2019): decreasing public empathy toward poor people (Direction Générale de la Cohésion Sociale [DGCS], 2017: 12); the lowest social trust (4.61) among the western European and other neighboring countries (European Social Survey, 2018) ${ }^{1}$; $73.56 \%$ believing social cohesion to be "not very strong" or "not at all strong" (Direction de la Recherche, des Etudes, de l'Evaluation et des Statistiques [DREES], 2020); and $67.82 \%$ saying that the government does either too much or too little for poor people. Burgeoning protest movements have also raised concerns over the state of social cohesion. For example, the Yellow Vest movement that began in 2018 has revealed deep institutional distrust and agitated the social order, increasing the sense of crisis in social cohesion. The protest movement especially reflected frustrations over growing inequalities-whose forms have become more diversified and pervasively present in social relationships-with numerous protestors demanding an increase in redistribution and improvements in social equity (Dubet, 2014; Keller and Lafont, 2020; SES-ENS, 2018; Teyssedre and Le Bouler, 2019).

In fact, over the last decade, a growing perception of inequality has been a major issue in France. Low-income households' quality of life has been degraded, while their financial insecurity has increased. Inequalities of employment opportunity between territorial units have accentuated center-periphery and urban-rural disparities (CGET, 2018: 8-31). Moreover, DREES (2020) Opinion Barometer Survey results indicate increasing perceptions of inequality: between 2008 and 2019, 83.93\% believed that inequalities had increased during the last five years, a value that is 10 percentage points higher than the value in the pre-crisis period (2000-2007, 73.92\%). Given that preventing social exclusion is fundamental for building a cohesive society (Dahrendorf et al., 1995; Kronauer, 1998), the current state is quite alarming.

Lower social cohesion can result in negative social consequences. For instance, a high level of inequalities, a potential indicator of weaker social cohesion, can lead to higher crime rates, undermine public well-being and a sense of community, and disrupt the social fabric (Berger-Schmitt, 2000; Kawachi and Kennedy, 1997; Kearns and Forrest, 2000; Rueda and Stegmueller, 2016; Wilkinson and Pickett, 2009). For a conflictual society lacking in social order, growth can be hindered, and high economic costs may have to be borne (Collier, 1999; de Melo et al., 1996). Additionally, intergroup hatred and discrimination, which are risk factors for social cohesion (Kearns and Forrest, 2000: 998), can lower well-being and strengthen exclusive in-group identities, thus increasing social fragmentation (Branscombe et al., 1999; Verkuyten and Yogeeswaran, 2017).

On the other hand, various aspects of social cohesion have benefits for individuals and society, namely, improvements in quality of life and overall social, economic, and health outcomes (Stanley, 2003). For example, social capital is associated with 
good health, longevity, and subjective well-being (Berkman and Syme, 1979; Portela et al., 2013). It also contributes to economic growth, prosperous communities, and well-functioning democracy (Daly and Silver, 2008; Helliwell and Putnam, 1995; Paxton, 2002). Shared values foster cooperation, reduce conflicts, and contribute to building a more harmonious society (Schwartz and Sagie, 2000: 466), and they provide individuals with opportunities to experience fulfillment and life satisfaction (Sagiv et al., 2012).

Hence, when social cohesion declines, not only can there be broad negative ramifications, but a society may be unable to fully benefit from its positive externalities. In this respect, signs of a fragile state of social cohesion in post-crisis France suggest that individual and societal well-being is also being challenged. Thus, by analyzing the associations between micro- and macroeconomic conditions and social cohesion attitudes in the last decade, this study aims to derive broad implications for different dimensions of social cohesion. The case of France will offer insights into the proposed link, especially considering that the recent Yellow Vest movement broadly called into question the state of social cohesion within the contexts of macroeconomic slowdown and growing inequalities.

To my knowledge, no prior research has examined the association between micro-macro-economic conditions and social cohesion in France through statistical modeling. Another distinguishing feature of this study is that social cohesion is operationalized and analyzed by drawing on the interlinkage between its dimensions. The rationale for this approach is the claim in previous studies that social cohesion dimensions are closely interrelated and affect each other (Green et al., 2003; Kearns and Forrest, 2000: 996). In most previous studies, the interlinkage among dimensions has been proposed at the conceptual, theoretical level (Janmaat, 2011), whereas this study has empirically based implications concerning such linkages.

\section{Concept and operationalization of social cohesion}

There is no academic consensus on the definition of social cohesion (Jenson, 2010), and it is necessary to have a clear concept of social cohesion before proceeding to the analysis. This study uses Kearns and Forrest's (2000: 996) concept of social cohesion, according to which a cohesive society is one that "hangs together", where "all the component parts somehow fit in and contribute to society's collective project and well-being; and conflict between societal goals and groups, and disruptive behaviors are largely absent or minimal". Of the five dimensions of social cohesion proposed by Kearns and Forrest (2000), this study analyzes the following four: social networks and social capital, social solidarity and reductions in wealth disparities, social order and social control, and common values and a civic culture. The latter will be studied in connection with the former three. The remaining territorial belonging and identity dimension is not considered in the present study due to the limited availability of data; the corresponding ESS item on place attachment (How emotionally attached do you feel to [country]?) was introduced only in 2016 (round 8). Additionally, a review of the related literature reveals that each level of place attachment (e.g., neighborhood, country) is associated with economic conditions 
differently, and considering various territorial scales is necessary (Bailey et al., 2012; Hierro and Rico, 2019). Such an endeavor is beyond the scope of this study.

\section{Social networks and social capital dimension}

The social networks and social capital (hereinafter social capital) dimension reflects the Putnamian approach to social cohesion. Putnam (2001) defines social capital as "connections among individuals-social networks and the norms of reciprocity and trustworthiness that arise from them". Social capital, as a building block of social cohesion, reinforces its core traits (Schmeets and te Riele, 2014). In this study, I will use social trust as a partial indicator of this dimension. Social trust is known to facilitate collective action and cooperation (Kearns and Frost, 2000) and is one of the most frequently considered elements of social capital in the literature.

\section{Social solidarity and reductions in wealth disparities dimension}

In operationalizing the social solidarity and reductions in wealth disparities (hereinafter solidarity) dimension, several indicators can be considered, such as welfare state generosity or equal access to welfare. Individual-level indicators include a person's interest in the well-being of members of a society, the willingness to assist (Kearns and Forrest, 2000: 999), or individuals' support for equality conceived as an expression of fraternal solidarity (Dubet, 2014). The latter is also a determining factor for redistributive policy that helps sustain a society's cohesion (Reeskens and van Oorschot, 2015). This dimension echoes Durkheim's conception of social cohesion, which sees equality as a necessary condition for a cohesive society (Herzog, 2018: 123).

As a partial indicator of the solidarity dimension, I will consider support for equality, specifically focusing on the aspect of attitudinal variation rather than the individual's level of egalitarianism. This method of operationalization is based on French society's overall high degree of support for equality and various motivations that underlie this attitude. France has higher public support for equality and redistribution than most other European countries (European Social Survey, 2018) ${ }^{2}$. Therefore, relatively low levels of support for equality in the French context may not necessarily indicate a lack of solidarity toward others in absolute terms. In addition, a range of motivations underlie this attitude, from concern for self-interest to empathy to co-citizens. The infeasibility of disentangling motivations behind the ESS item support for equality — which will be used in this study-renders it difficult to interpret a higher level of support for equality as an expression of solidarity toward co-citizens, a key definitional element of this dimension (Kearns and Forrest, 2000: 999). Given the above, I will not consider the level itself but analyze only the attitudinal dispersion.

This manner of operationalization is particularly relevant to the reality of France, where attitudinal dispersion over egalitarianism is of greater concern than the absolute level of egalitarian support. Notably, the Yellow Vest movement exemplified a conflict that can arise from different views on equality and redistribution. Moreover, 
the proposed operationalization essentially draws on the interlinkage between the dimensions of solidarity and common values and a civic culture, as will be further explained below.

\section{Social order and social control dimension}

The social order and social control (hereinafter social order) dimension refers to the "absence of general conflict and of serious challenge to the existing order". Its key contributing elements are intergroup cooperation, respect for differences, and lack of hatred-_for example, between different ethnic groups" (Kearns and Forrest, 2000: 998). As a partial indicator of this dimension, I will analyze anti-immigration attitudes. A more negative attitude toward immigrants will be interpreted as having adverse implications for the intergroup relations and thus for the social order dimension.

\section{Common values and a civic culture dimension}

As mentioned in the previous section, this study draws on the interconnectedness among different dimensions of social cohesion (Kearns and Forrest, 2000). In particular, the dimension of common values and a civic culture (hereinafter common values dimension) is closely linked with other attitudinal aspects of social cohesion. From the common values perspective, social cohesion emerges from society members' mutual sharing of a set of values and moral principles (Kearns and Forrest, 2000; 997). Then, higher levels of dispersion in core attitudes within society can be considered negative for social cohesion. For instance, larger variations in public preferences regarding egalitarianism, an indicator of the solidarity dimension, can be detrimental to the common values dimension. Accounting for such linkages, the common values dimension will be operationalized as intergroup dispersion in social cohesion attitudes, namely, social trust, support for equality, and immigration attitudes.

\section{Theories and hypotheses}

\section{Individual economic conditions and social capital}

Previous research has argued that social capital is unevenly distributed depending on individuals' resources (Schlozman et al., 1999). Economic strain, for example, is a strong predictor of lower social and institutional trust and weaker civic integration (Delhey and Newton, 2003, 111; Vergolini, 2011). According to the reference group theory (Merton and Kitt, 1950), people frequently compare their own situations to those of other social groups. In this process, economically strained individuals tend to experience resentful feelings toward other groups (Andrews et al., 2014), which can weaken their interpersonal social capital. Similarly, the risk aversion and resource approaches suggest that economically strained individuals can be 
less trusting of others due to their risk-averse tendencies and resource constraints. Being less able or willing to bear the cost of unreciprocated trust, strained individuals can display lower social trust, in part to avoid the risk of potential betrayal. On the contrary, those who are financially well-off with more resources tend to less fear the risk of being unreciprocated in the trust they put in others.

H1a: The higher the individual economic strain is, the lower the social trust

\section{Micro-macro-economic conditions and social capital}

In general, economically vulnerable individuals are more negatively affected by macroeconomic recessions than well-off individuals are (American Psychological Association, 2009). Thus, when the economy contracts, strained individuals can potentially be more swayed by pessimism, which tends to grow in times of economic hardship (Uslaner, 2000: 589; Uslaner and Brown, 2005: 870). Then, potentially through the combination of pessimism and senses of relative deprivation and resentfulness, strained individuals can have even lower social trust in such periods (Fairbrother and Martin, 2013: 349). As a result, larger variations in social trust levels across economic groups can arise, which is detrimental to the common values dimension. Empirically, Dotti Sani and Magistro (2016) found that a decline in institutional trust during the recession period was more apparent among the lower strata.

\section{$\mathrm{H} 1 \mathrm{~b}$ : Macroeconomic conditions moderate the correlation between individual economic strain and social trust.}

\section{Individual economic conditions and egalitarian attitudes}

According to self-interest theory (Blekesaune, 2007), current and prospective welfare recipients in financially stringent circumstances are more likely to support egalitarian measures because these policies benefit them. Reflecting self-interest, indicators of lower socioeconomic status, such as job uncertainty, low income, poor health, and less education, are discussed as being associated with support for redistribution (Baslevent and Kirmanoglu, 2011; Jæger, 2006).

H2a: The higher the economic strain is, the stronger the support for equality.

\section{Micro-macro-economic conditions and egalitarian attitudes}

Previous literature argues that individuals can become more self-centered during an economic downturn (Fisman et al., 2014; Sihvo and Uusitalo, 1995). Then, when the economy contracts, the self-interest mechanism could be more decisive in determining individuals' redistributive preference. Additionally, macroeconomic 
deterioration, which exposes strained individuals to greater risks in terms of employment, health, and housing, tends to heighten their vigilance to threats while reducing their sense of control over life (Kraus et al., 2012; Manstead, 2018). Thus, in such contexts, strained individuals can express stronger demand for egalitarian measures, particularly to compensate for their weakened sense of control over life outcomes. On the other hand, well-off individuals, as primary contributors to state welfare, can show lower levels of support for such measures given the expected rise in social spending costs. Then, at the societal level, there can be larger variations or even polarization in the public's preferences regarding equality and redistribution (Fisman et al., 2014; Rosset and Pontusson, 2014), posing a risk to the common values dimension.

\section{$\mathrm{H} 2 \mathrm{~b}$ : Macroeconomic conditions moderate the correlation between individual economic strain and support for equality.}

\section{Individual economic conditions and immigration attitudes}

Labor market competition theory proposes that people are particularly opposed to the inflow of migrants with similar labor skills (Malhotra et al., 2013). The majority of recent immigrants to France have low levels of skills and education (Domergue, 2012), and natives who are similarly less skilled and economically insecure could thus perceive higher levels of threat from immigration and demonstrate stronger preferences for restrictive immigration policies (Scheve and Slaughter, 2001). In a similar vein, group conflict theory contends that economically vulnerable individuals have more negative immigration attitudes due to their strong perception of competition with immigrants for scarce resources such as jobs and welfare (Billiet et al., 2014; Lancee and Pardos-Prado, 2013).

H3a: The higher the economic strain is, the stronger the anti-immigration attitude.

\section{Micro-macro-economic conditions and immigration attitudes}

In times of economic hardship, economically disadvantaged people's vigilance to threats tends to be heightened, resulting in a greater perceived threat from immigration (Ceobanu and Escandell, 2010; Manstead, 2018). Thus, as the economy contracts, strained people can show greater hostility and prejudice toward immigrants (Semyonov et al., 2006). Then, the gap in opinions toward immigration can widen between financially well-off and strained people, posing a challenge to the common values dimension. In contrast, in times of prosperity, economically disadvantaged people can perceive immigrants' arrival to have less impact on competition for resources and their well-being, likely reducing negative attitudes toward immigration (Kehrberg, 2007). 


\section{H3b: Macroeconomic conditions moderate the correlation between individual economic strain and anti-immigration attitudes}

\section{Data, variables, and method}

\section{Data}

This study uses repeated cross-sectional European Social Survey (ESS) data pooled from rounds 4 (2008) to 9 (2018). The survey is biennially conducted in more than thirty European countries. It consists of a core module on themes such as media and social trust, politics, and subjective well-being; rotating modules; and sociodemographic questions. The ESS dataset is suitable for this study because it includes various indicators of different dimensions of social cohesion.

\section{Dependent variable: social cohesion attitudes}

Social trust is chosen as an indicator of the social capital dimension. Following Economou et al. (2014), three internally consistent items were averaged to generate a composite social trust variable. The three questions used are as follows: Would you say that most people can be trusted or that you can't be too careful in dealing with people? Do you think that most people would try to take advantage of you if they got the chance, or would they try to be fair? Would you say that most of the time people try to be helpful or that they are mostly looking out for themselves? Each question was answered on an 11-point scale, with higher scores indicating higher social trust.

To operationalize the solidarity dimension, I chose a single item on egalitarian attitude (Rueda and Stegmueller, 2016): To what extent do you agree or disagree with the statement: the government should take measures to reduce differences in income levels. The 5-point scale item was reverse-coded so that higher scores indicate stronger support for equality.

As an indicator of the social order dimension, I use a composite anti-immigration attitude variable created based on the responses to three immigration items: To what extent do you think the country should allow people of the same race or ethnic group as most people of the country to come and live here? How about people of a different race or ethnic group from most people? How about people from the poorer countries outside Europe? Respondents chose from four response options: 4 -Allow none; 3 - Allow a few; 2 - Allow some; and 1 - Allow many. Following Davidov and Meuleman (2012), the three items were averaged to generate a composite score, with higher scores indicating stronger opposition to immigration.

\section{Independent variable: economic strain}

Economic strain is a subjective measure of an individual's economic condition, indicating financial distress or difficulties in meeting financial needs. The ESS 
objective income measure was not ideal for use due to its higher nonresponse rate $(8.96 \%)$ compared to rate for the economic strain item $(0.40 \%)$. For similar reasons, previous research used a strain variable as an alternative to objective income (Dinesen, 2013).

Furthermore, economic strain can be a better predictor of social cohesion attitudes because it is closely intertwined with a person's thoughts, behaviors, and emotions, as well as reflecting experiences accumulated over a lifetime (Glei et al., 2018: 24; Kraus et al., 2011). Additionally, economic strain is known to have wide-ranging individual and social consequences relevant to social cohesion, such as less favorable health outcomes or elevated risk of social unrest and fractures (Glei et al., 2018).

A single item was used to measure economic strain: Which of the descriptions comes closest to how you feel about your household's income nowadays? Respondents chose among four options: 1-Living comfortably on present income; $2-$ Coping on present income; 3-Finding it difficult on present income; and 4-Finding it very difficult on present income.

\section{Moderator variables: macroeconomic variables}

To investigate how micro-macro-economic conditions are associated with social cohesion attitudes, I will test cross-level interactions between individual economic strain and contextual economic indicators. For this purpose, I include two macroeconomic variables as moderators: GDP growth and unemployment rates. GDP growth measures the overall economic well-being (Callen, 2008) or "changes in economic condition" (Chen, 2010). The unemployment rate is another commonly used indicator of macroeconomic conditions (Rosenfeld and Fornango, 2007). GDP growth data were obtained from the World Bank (2020), and unemployment data were taken from the OECD (2020) database. I choose either GDP growth or unemployment rate for the analysis of each dependent variable according to the underlying theories. For social trust and egalitarian attitudes, I use the GDP growth rate. For anti-immigration attitudes, I use the unemployment rate because both labor market competition and group conflict theories suggest that the context of job scarcity is particularly relevant to immigration attitudes.

\section{Control variables}

I control for sociodemographic variables known to influence social cohesion attitudes: age, gender, education level, marital status, having children, immigration status, religiosity, place of residence, political orientation, main activity, unemployment experience, and discrimination (Busemeyer and Neimanns, 2017; Delhey and Newton, 2003; Kesler and Bloemraad, 2010; Van Oorschot, 2002). Some variables were recoded to facilitate interpretation. Regarding immigration status, individuals who were not born in the country were coded as immigrants, with the natives as the reference group (Fjær et al., 2017). Religiosity is measured by the frequency of church attendance regardless of denominations. The dichotomous discrimination 
variable takes a value of 1 if an individual perceives himself or herself to be a member of a group that is discriminated against in the country. Previous studies have reported significant effects of discrimination experience on social trust (Delhey and Newton, 2003: 96) and support for equality (Fried et al., 2001).

\section{Method}

To examine the correlation between economic conditions and social cohesion attitudes, I fit three pooled OLS regression models with year fixed effects for each social cohesion attitude. Researchers often utilize a multilevel random-effects model to analyze individual (micro) and contextual (macro) factors simultaneously. However, the pooled data used in this research have a small number of level 2 (survey year) units-six in total, rendering the application of a multilevel approach inappropriate. Hence, alternatively, I use a fixed effects model as recommended in previous studies (Möhring, 2012; Bennett and Möhring, 2015). This approach accounts for unobserved year-level heterogeneity, thus alleviating the concern of omitted variable bias, and allows the inclusion of macro-level variables as a moderator in the cross-level interaction (Möhring, 2012). Since the year fixed effects model with survey year dummies accounts for all the variance at the yearlevel, including macro independent variables that vary uniquely over time creates a problem of perfect collinearity (Andreß et al., 2019; Bell et al., 2019). Thus, rather than estimating the direct effects of macro variables, I estimate only crosslevel interaction, through which I investigate whether social cohesion attitudes are likely to become more dispersed across wealth groups when macroeconomic conditions deteriorate $(H 1 b, H 2 b, H 3 b)$.

All models are weighted using the design weight variable provided in the ESS dataset. After estimating the pooled OLS models, I perform regression diagnostics to assess the assumptions of linearity, heteroskedasticity, multicollinearity, and normal distribution. The diagnostics revealed that these assumptions are generally met except for the heteroskedasticity assumption. To remedy this issue, robust standard errors were estimated using Huber-White sandwich estimators. Cluster robust standard errors computed in Stata were not appropriate for data with a small number of clusters (Esarey and Menger, 2019).

As a robustness check, I rerun the regressions using a bootstrap-t standard error procedure: an approach recommended in a number of recent studies to account for the clustered data structure in the presence of a very low number of clusters (Cameron et al., 2008; Cameron and Miller, 2015). I also estimate the models separately for each ESS wave to test the stability of individual-level estimates. In the following section, I report the main empirical results and the robustness checks (Table 1). 


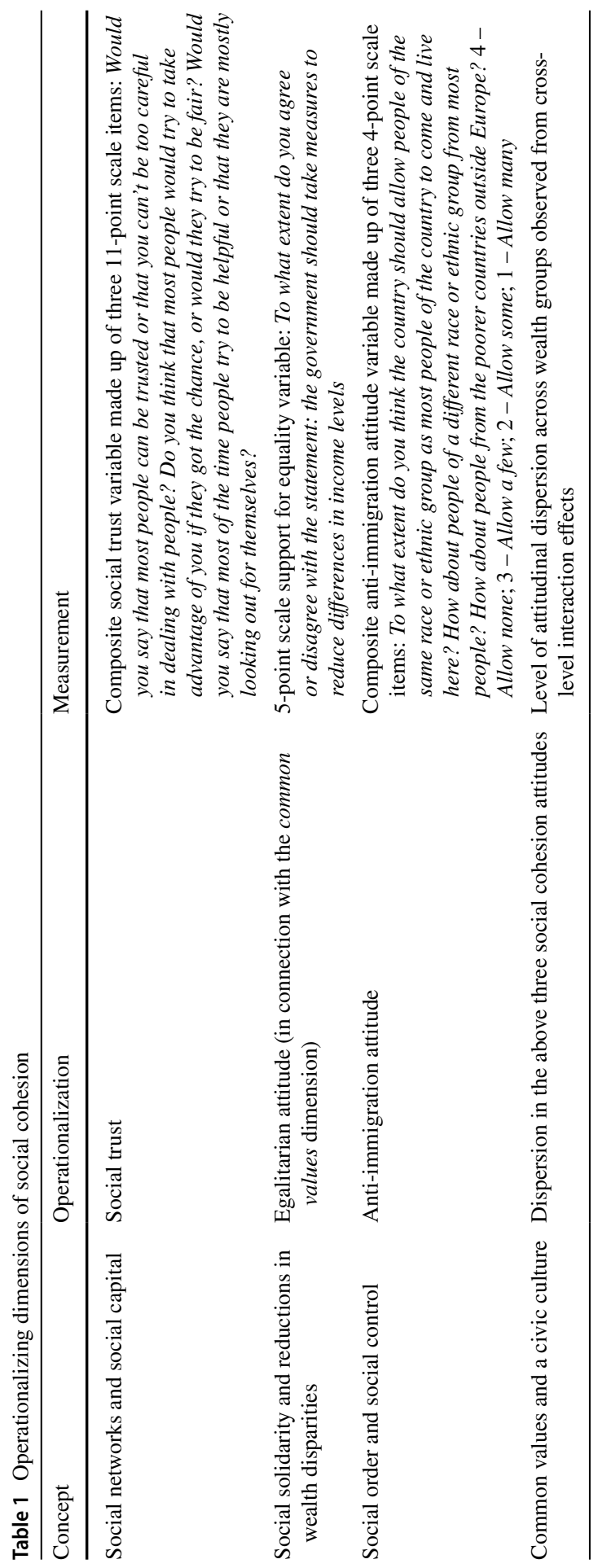




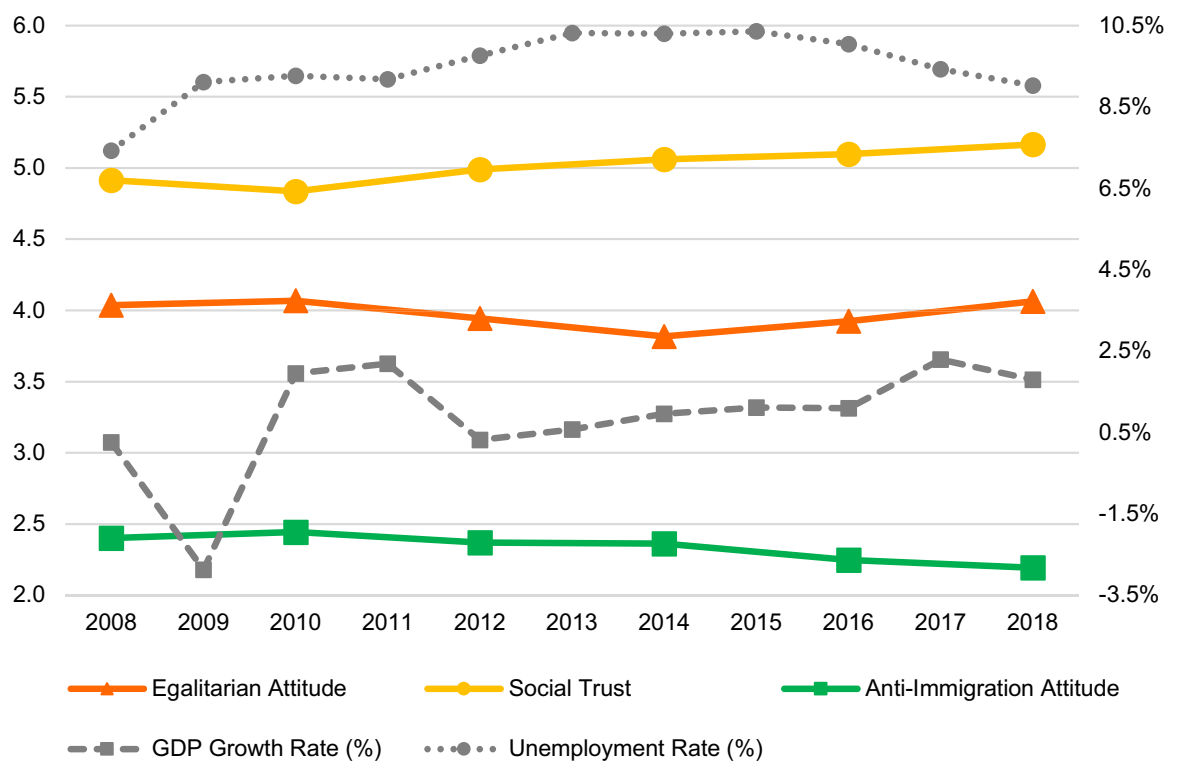

Fig. 1 Social cohesion attitudes and macroeconomic indicators (2008-2018)

\section{Results}

Figure 1 illustrates the changes in social cohesion attitudes and contextual economic conditions (GDP growth and unemployment rates) in France over the past 10 years. For social cohesion attitudes, slight changes are observed. Opposition to immigration decreased from a score of 2.40 (2008) to 2.19 (2018). Egalitarian attitudes show an overall decreasing trend until 2014, after which an increasing trend is observed. For social trust, 2010 marks the lowest point (4.84), followed by slight increases in subsequent years.

Between 2008 and 2018, GDP growth was the lowest in 2009 (-2.87\%), in the aftermath of the global economic crisis. Among the years in which the ESS was conducted, 2008 marked the lowest point $(0.25 \%)$. In 2010, the French economy started to recover moderately with improvements in exports (Boisnault et al., 2011), only to be followed by a prolonged period of slowdown until the recovery in 2017 (2.29\%). Concerning the unemployment rate, after a steep increase from 2008 (7.43\%) to $2009(9.11 \%)$, the value remained high until 2018 (9.03\%), although a slightly decreasing trend has been observed since 2016.

Figure 2 illustrates the changes in the proportion of individuals feeling economic strain (difficult on present income or very difficult on present income) over the postcrisis period. The increasing trend is clear, except for a temporary decline in 2016 (18.9\%), probably against the backdrop of some improvement in the economic situation after a prolonged slowdown. Overall, the figure suggests that perceptions of economic insecurity continuously increased at the societal level in the given period. 


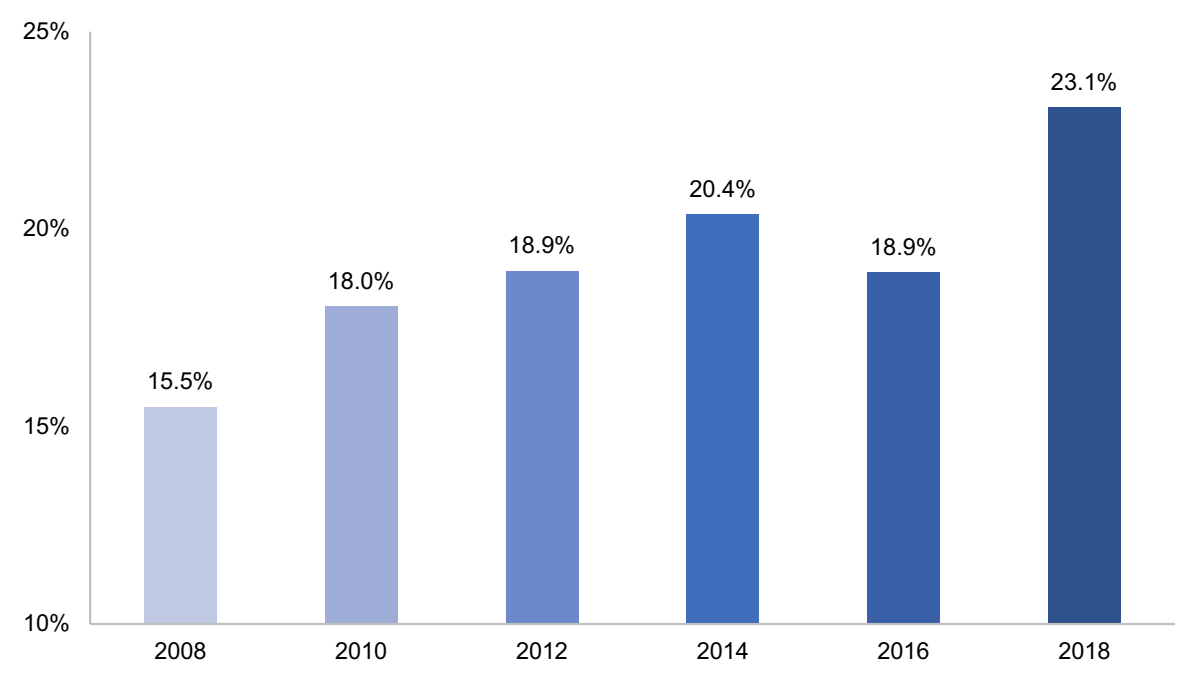

Fig. 2 Percentage of individuals feeling economic strain (2008-2018)

Table 2 reports the results of pooled OLS estimating the correlations between economic conditions and three types of social cohesion attitudes: social trust (social capital dimension), egalitarian attitudes (solidarity dimension), and anti-immigration attitudes (social order dimension). All models were controlled for year fixed effects to account for unobserved year-level heterogeneity.

Model 1 investigates the correlation between economic conditions and social trust. Economic strain is associated with lower social trust $(\beta=-0.319 * * *)$, supporting Hla. This result is consistent with the reference group (Andrews et al., 2014), risk aversion (Ananyev and Guriev, 2018), and resource approaches (Brady et al., 1995), which suggest that resentment toward other social groups, reluctance to take risks, and resource constraints are the main underlying reasons for strained individuals' lower social capital. The cross-level interaction between GDP growth and economic strain is not significant, thus refuting $H 1 b$. This result indicates that the association between individual economic conditions and social trust is not moderated by macroeconomic conditions. Some control variables are significantly correlated with social trust. For example, higher levels of religiosity $\left(\beta=0.196^{* * *}\right)$ and education $(\beta=0.512 * * *)$ are associated with greater social trust, while the perception of being discriminated against lowers social trust $\left(\beta=-0.631^{* * *}\right)$ (Rothstein and Stolle, 2003).

Model 2 examines the correlation between economic conditions and support for equality. In general, greater economic strain is associated with stronger support for equality $\left(\beta=0.156^{* * *}\right)$, thus supporting $H 2 a$. In line with self-interest theory, the result suggests that concern for one's own interests can be a significant factor in the formation of redistributive and egalitarian preferences (Jæger, 2006). Confirming $H 2 b$, the cross-level interaction between GDP growth and economic strain is statistically significant $(\beta=-0.048 *)$. 
Table 2 Pooled OLS of social cohesion attitudes on economic conditions (with year fixed effects)

\begin{tabular}{|c|c|c|c|}
\hline Dependent variable & $\begin{array}{l}\text { Model } 1 \\
\text { Social trust }\end{array}$ & $\begin{array}{l}\text { Model } 2 \\
\text { Egalitarian attitude }\end{array}$ & $\begin{array}{l}\text { Model } 3 \\
\text { Anti-immigration attitude }\end{array}$ \\
\hline Social Cohesion Dimension & Social Capital & Solidarity & Social Order \\
\hline Economic strain & $\begin{array}{l}-0.319 * * * \\
{[0.027]}\end{array}$ & $\begin{array}{l}0.156^{* * * *} \\
{[0.018]}\end{array}$ & $\begin{array}{l}0.120 * * * \\
{[0.012]}\end{array}$ \\
\hline GDP growth*Economic strain & $\begin{array}{l}0.018 \\
{[0.038]}\end{array}$ & $\begin{array}{l}-0.048 * \\
{[0.024]}\end{array}$ & \\
\hline Unemployment rate*Economic strain & & & $\begin{array}{l}0.029 * * \\
{[0.011]}\end{array}$ \\
\hline Age & $\begin{array}{l}0.005^{* *} \\
{[0.002]}\end{array}$ & $\begin{array}{l}0.003 * * \\
{[0.001]}\end{array}$ & $\begin{array}{l}0.004 * * * \\
{[0.001]}\end{array}$ \\
\hline Female (Ref: Male) & $\begin{array}{l}0.116 * * * \\
{[0.034]}\end{array}$ & $\begin{array}{l}0.119 * * * \\
{[0.024]}\end{array}$ & $\begin{array}{l}0.013 \\
{[0.015]}\end{array}$ \\
\hline \multicolumn{4}{|l|}{ Education (Ref: ISCED 2 and below) } \\
\hline ISCED 3 and 4 & $\begin{array}{l}0.100 * \\
{[0.045]}\end{array}$ & $\begin{array}{l}-0.007 \\
{[0.030]}\end{array}$ & $\begin{array}{l}-0.139 * * * \\
{[0.020]}\end{array}$ \\
\hline ISCED 5 and 6 & $\begin{array}{l}0.512 * * * \\
{[0.049]}\end{array}$ & $\begin{array}{l}-0.292 * * * \\
{[0.035]}\end{array}$ & $\begin{array}{l}-0.412 * * * \\
{[0.022]}\end{array}$ \\
\hline Other & $\begin{array}{l}-0.021 \\
{[0.484]}\end{array}$ & $\begin{array}{l}-0.548 \\
{[0.489]}\end{array}$ & $\begin{array}{l}0.033 \\
{[0.230]}\end{array}$ \\
\hline Married (Ref: Unmarried) & $\begin{array}{l}-0.030 \\
{[0.038]}\end{array}$ & $\begin{array}{l}0.000 \\
{[0.025]}\end{array}$ & $\begin{array}{l}0.000 \\
{[0.016]}\end{array}$ \\
\hline Children at home (Ref: No) & $\begin{array}{l}-0.003 \\
{[0.038]}\end{array}$ & $\begin{array}{l}-0.059 * \\
{[0.027]}\end{array}$ & $\begin{array}{l}0.041 * \\
{[0.017]}\end{array}$ \\
\hline Native-born (Ref: Immigrant) & $\begin{array}{l}-0.087 \\
{[0.061]}\end{array}$ & $\begin{array}{l}0.102 * \\
{[0.045]}\end{array}$ & $\begin{array}{l}0.133 * * * \\
{[0.025]}\end{array}$ \\
\hline Religious (Ref: Not religious) & $\begin{array}{l}0.196 * * * \\
{[0.054]}\end{array}$ & $\begin{array}{l}-0.083^{*} \\
{[0.038]}\end{array}$ & $\begin{array}{l}-0.116^{* * * *} \\
{[0.022]}\end{array}$ \\
\hline Urban (Ref: Rural) & $\begin{array}{l}0.043 \\
{[0.035]}\end{array}$ & $\begin{array}{l}-0.006 \\
{[0.024]}\end{array}$ & $\begin{array}{l}-0.080 * * * \\
{[0.015]}\end{array}$ \\
\hline Left-right scale & $\begin{array}{l}-0.031 * * * \\
{[0.008]}\end{array}$ & $\begin{array}{l}-0.112^{* * * *} \\
{[0.005]}\end{array}$ & $\begin{array}{l}0.084 * * * \\
{[0.003]}\end{array}$ \\
\hline \multicolumn{4}{|l|}{ Main Activity (Ref: Employed) } \\
\hline Unemployed & $\begin{array}{l}-0.185^{*} \\
{[0.081]}\end{array}$ & $\begin{array}{l}-0.037 \\
{[0.053]}\end{array}$ & $\begin{array}{l}0.055 \\
{[0.037]}\end{array}$ \\
\hline Education & $\begin{array}{l}0.348 * * * \\
{[0.082]}\end{array}$ & $\begin{array}{l}-0.021 \\
{[0.057]}\end{array}$ & $\begin{array}{l}-0.164 * * * \\
{[0.039]}\end{array}$ \\
\hline Sick or disabled & $\begin{array}{l}-0.322 * \\
{[0.130]}\end{array}$ & $\begin{array}{l}0.020 \\
{[0.083]}\end{array}$ & $\begin{array}{l}0.043 \\
{[0.049]}\end{array}$ \\
\hline Other inactive & $\begin{array}{l}0.068 \\
{[0.056]}\end{array}$ & $\begin{array}{l}0.033 \\
{[0.036]}\end{array}$ & $\begin{array}{l}0.071 * * \\
{[0.023]}\end{array}$ \\
\hline Ever unemployed $>3$ months & $\begin{array}{l}-0.107 * * \\
{[0.038]}\end{array}$ & $\begin{array}{l}0.059 * \\
{[0.026]}\end{array}$ & $\begin{array}{l}-0.008 \\
{[0.016]}\end{array}$ \\
\hline
\end{tabular}


Table 2 (continued)

\begin{tabular}{llll}
\hline Dependent variable & $\begin{array}{l}\text { Model 1 } \\
\text { Social trust }\end{array}$ & $\begin{array}{l}\text { Model 2 } \\
\text { Egalitarian attitude }\end{array}$ & $\begin{array}{l}\text { Model 3 } \\
\text { Anti-immigration attitude }\end{array}$ \\
\hline Discrimination (Ref: No) & $-0.631 * * *$ & -0.003 & -0.012 \\
& {$[0.059]$} & {$[0.042]$} & {$[0.025]$} \\
Year dummies & Yes & Yes & Yes \\
Constant & $4.669 * * *$ & $4.407 * * *$ & $1.933 * * *$ \\
$R^{2}$ & {$[0.122]$} & {$[0.083]$} & {$[0.050]$} \\
Adjusted $R^{2}$ & 0.091 & 0.108 & 0.218 \\
F-statistic & 0.089 & 0.106 & 0.216 \\
$N$ & $33.671 * * *$ & $37.218 * * *$ & $104.174 * * *$ \\
\hline
\end{tabular}

Note Robust standard errors in brackets. $* p<0.05$, ** $p<0.01$, *** $p<0.001$. All results were weighted using ESS design weights. The main variables were mean centered to avoid multicollinearity

To visualize the cross-level interaction between economic strain and GDP growth, predictive margins are calculated and plotted in Fig. 3a and b. Figure 3a demonstrates that the positive effect of strain on support for equality is somewhat reduced when GDP growth is higher. The figure also shows that in the case of strained individuals (strain $\geqq 3$ ), support for equality tends to be higher at a lower GDP growth rate and lower at a higher GDP growth rate. A reverse tendency is found for the most well-off individuals (strain $=1$ ), who show higher support for equality at a higher GDP growth rate and slightly lower support at a lower GDP growth rate. Figure $3 b$ shows the same information yet highlights the variations in egalitarian preferences across economic groups for a range of GDP growth rates. A larger distance between the lines at lower GDP growth rates indicates a larger dispersion in the degree of support for equality across economic groups in the economic hardship context; such gaps tend to narrow as the GDP growth rate increases.

Several control variables are significantly correlated with egalitarian attitudes. Those on the political left tend to have higher support for equality $(\beta=-0.112 * * *)$. This result is consistent with the political ideology approach, which contends that individuals' values and beliefs influence their redistributive preferences (Jæger, 2006). The most highly educated group is in general less egalitarian than the least educated group $(\beta=-0.292 * * *)$, which implies that in France, the education effect reflects the interests of higher social status more than the egalitarian socialization outcome of schooling (Hasenfeld and Rafferty, 1989). Past unemployment experience of over three months is associated with stronger support for equality $\left(\beta=0.059^{*}\right)$. Such long-term exposure to economic vulnerability may increase risk aversion and predispose individuals to support government responsibility for redistribution.

Model 3 explores the correlation between economic conditions and anti-immigration attitudes. As predicted by labor market competition and group conflict theories, strained individuals tend to be more opposed to immigration than well-off individuals are $\left(\beta=0.120^{* * *}\right)$. This result supports $H 3 a$. The result also suggests that, 


\section{a \\ Predictive margins}

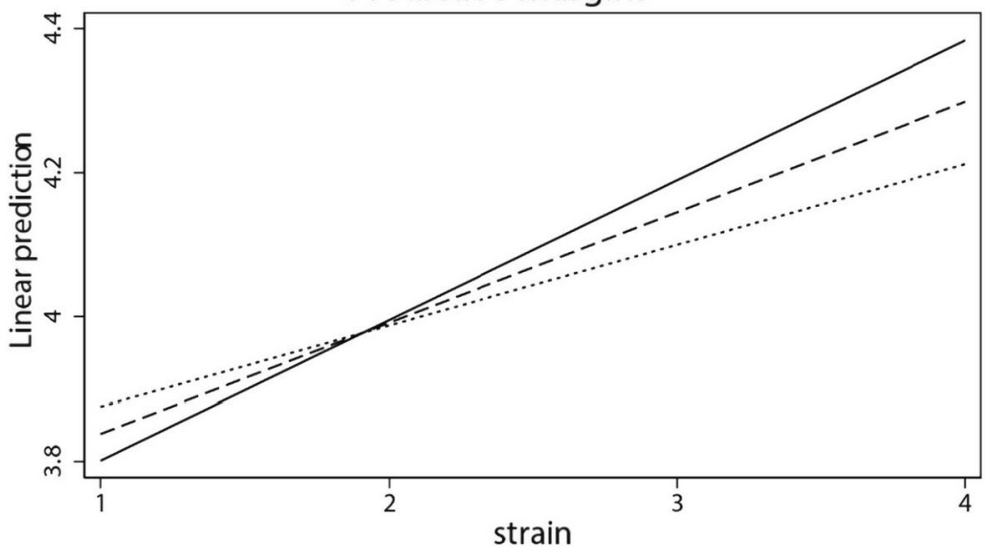

GDP growth rate

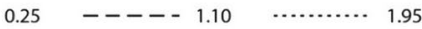

b

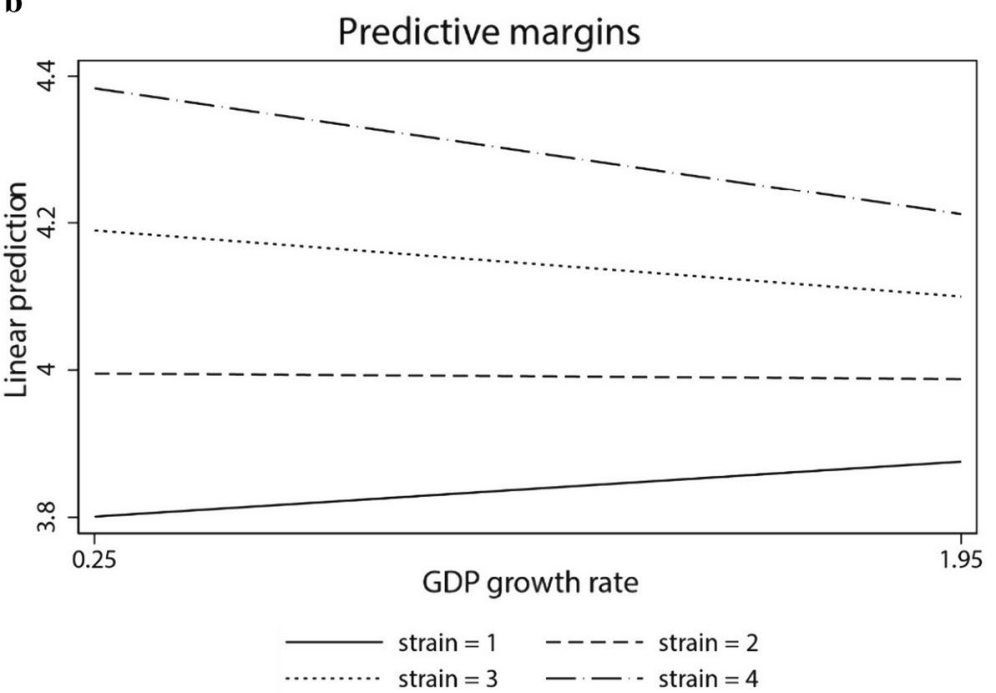

Fig. 3 a Interaction between economic strain and GDP growth on support for equality (1) Note: Three representative values of GDP growth rates were selected for ease of interpretation. All predictive margins were statistically significant $(p<0.001)$ (results available upon request). Mean centered variables were used in the analysis; however, the plot is labeled with the original values for readability. b. Interaction between economic strain and GDP growth on support for equality (2) Note: All predictive margins were statistically significant $(p<0.001)$ (results available upon request). Mean centered variables were used in the analysis; however, the plot is labeled with the original values for readability

notwithstanding the overall downward trend of anti-immigrant sentiment in France over the last decade (Fig. 1), there exists an important attitudinal gap between affluent individuals and economically disadvantaged individuals. 

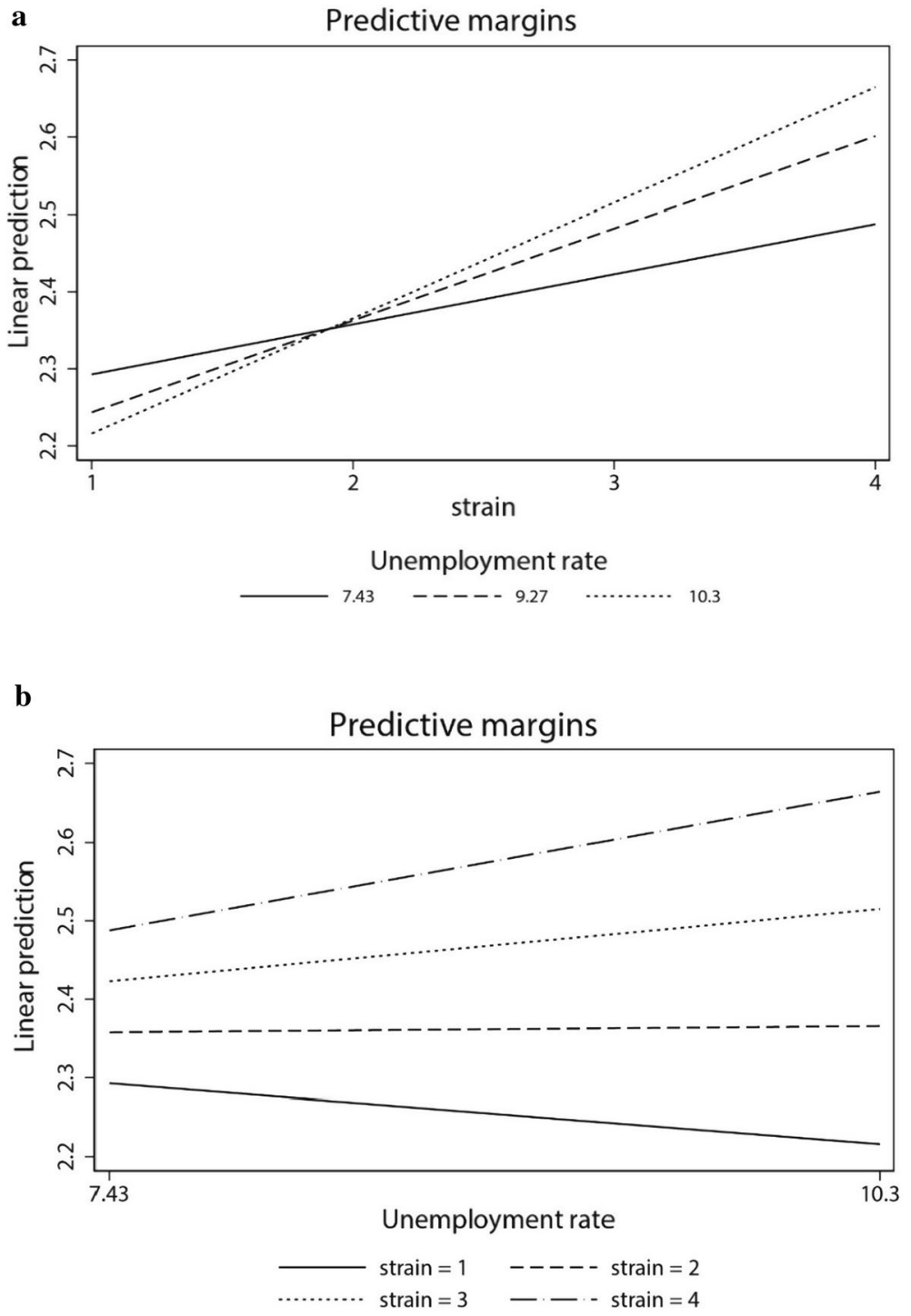

Fig. 4 a Interaction between economic strain and unemployment rate on anti-immigration attitudes (1) Note: Three representative values of unemployment rates were selected for ease of interpretation. All predictive margins were statistically significant $(p<0.001)$ (results available upon request). Mean centered variables were used in the analysis; however, the plot is labeled with the original values for readability. $\mathbf{b}$ Interaction between economic strain and unemployment rate on anti-immigration attitudes (2) Note: All predictive margins were statistically significant $(p<0.001)$ (results available upon request). Mean centered variables were used in the analysis; however, the plot is labeled with the original values for readability

A significant cross-level interaction is observed between economic strain and unemployment rate $(\beta=0.029 * *)$, thus supporting $H 3 b$. Figures $4 \mathrm{a}$ and $\mathrm{b}$ plot the predictive margins of the interaction effect. Figure 4 a shows that the positive effect 
of strain on anti-immigration attitudes is stronger to some degree when the unemployment rate is higher. The figure also shows that economically strained individuals (strain $\geqq 3$ ) tend to have higher opposition to immigration at a higher unemployment rate, whereas their views on immigration become more positive when the unemployment rate is lower. Conversely, the most well-off individuals (strain $=1$ ) show slightly lower opposition to immigration when the unemployment rate is higher and higher opposition when the unemployment rate is lower. Such tendencies of economically disadvantaged individuals and affluent individuals can potentially lead to wider attitudinal gaps when unemployment is high, as shown in Fig. 4b, which displays the same information with the unemployment rate on the horizontal axis. The plot well illustrates the increasing variations in immigration-related opinions across groups according to wealth as unemployment rises.

Several control variables are significantly associated with anti-immigration attitudes. Highly educated individuals are in general more pro-immigration than less educated individuals $(\beta=-0.412 * * *)$. Previous literature points out that education can cultivate critical and globally oriented ways of thinking and foster positive perceptions of immigration (Green et al., 2010). As expected, politically right-leaning individuals tend to be more opposed to immigration $(\beta=0.084 * * *)$.

Finally, I subjected the estimated models to two robustness checks. First, all the regressions were replicated using the bootstrap-t standard error procedure as an alternative to sandwich estimators: the estimation approach recommended for clustered data with a very small number of clusters. Table 3 reports the results of regression models estimated using Stata's user-written WCBREGRESS command (Yan and Lin, 2020), which incorporates Cameron et al.'s (2008) bootstrap method. The results were robust to this method, and the statistical significance level for some of

Table 3 Pooled OLS of social cohesion attitudes on economic conditions using the bootstrap-t standard error procedure

\begin{tabular}{llll}
\hline Dependent variable & Social trust & Egalitarian attitude & $\begin{array}{l}\text { Anti- } \\
\text { immigration } \\
\text { attitude }\end{array}$ \\
\hline Economic strain & $-0.319 * * *$ & $0.156^{* * *}$ & $0.120^{* * *}$ \\
GDP growth*Economic strain & {$[0.017]$} & {$[0.009]$} & {$[0.011]$} \\
Unemployment rate*Economic strain & 0.018 & $-0.048^{* * *}$ & \\
Year dummies & {$[0.017]$} & {$[0.010]$} & $0.029 * * *$ \\
Constant & & & {$[0.005]$} \\
$R^{2}$ & Yes & Yes & Yes \\
Adjusted $R^{2}$ & $4.669 * * *$ & $4.407 * * *$ & $1.933^{* * *}$ \\
$N$ & {$[0.095]$} & {$[0.050]$} & {$[0.047]$} \\
\hline
\end{tabular}

Note Bootstrap standard errors in brackets. $* p<0.05, * * p<0.01$, *** $p<0.001$. All results were weighted using ESS design weights. The main variables were mean centered to avoid multicollinearity. Control variables were included in all models but omitted from the table 
Table 4 Beta coefficient estimates of economic strain in year-specific OLS regressions

\begin{tabular}{|c|c|c|c|c|c|c|c|c|c|}
\hline \multirow{3}{*}{$\begin{array}{l}\text { Year } \\
2008\end{array}$} & \multicolumn{3}{|c|}{ Dep: social trust } & \multicolumn{3}{|c|}{ Dep: egalitarian attitude } & \multicolumn{3}{|c|}{$\begin{array}{l}\text { Dep: anti-immigration } \\
\text { attitude }\end{array}$} \\
\hline & \multicolumn{2}{|c|}{ Economic strain $\beta / \mathrm{SE}$} & \multirow{2}{*}{$\frac{\mathrm{aR}^{2}}{0.089}$} & \multicolumn{2}{|c|}{ Economic strain $\beta / \mathrm{SE}$} & \multirow{2}{*}{$\frac{\mathrm{aR}^{2}}{0.115}$} & \multicolumn{2}{|c|}{ Economic strain $\beta / \mathrm{SE}$} & \multirow{2}{*}{$\frac{\mathrm{aR}^{2}}{0.209}$} \\
\hline & $-0.316^{* * *}$ & {$[0.062]$} & & $0.186^{* * *}$ & {$[0.038]$} & & $0.063 *$ & {$[0.026]$} & \\
\hline 2010 & $-0.280 * * *$ & {$[0.067]$} & 0.064 & $0.129 * *$ & {$[0.043]$} & 0.09 & $0.088 * * *$ & {$[0.026]$} & 0.210 \\
\hline 2012 & $-0.334 * * *$ & {$[0.064]$} & 0.080 & $0.209 * * *$ & {$[0.041]$} & 0.098 & $0.157 * * *$ & [0.029] & 0.186 \\
\hline 2014 & $-0.288 * * *$ & {$[0.070]$} & 0.118 & $0.122 *$ & [0.048] & 0.123 & $0.116^{* * *}$ & {$[0.032]$} & 0.240 \\
\hline 2016 & $-0.396 * * *$ & {$[0.059]$} & 0.097 & $0.172 * * *$ & {$[0.043]$} & 0.094 & $0.173 * * *$ & {$[0.028]$} & 0.214 \\
\hline 2018 & $-0.274 * * *$ & [0.069] & 0.071 & $0.110 *$ & [0.047] & 0.069 & $0.125^{* * *}$ & {$[0.031]$} & 0.221 \\
\hline
\end{tabular}

Note Robust standard errors in brackets. $* p<0.05$, $* * p<0.01$, $* * * p<0.001$. All results were weighted using ESS design weights. The main variables were mean centered to avoid multicollinearity. Control variables were included in all models but omitted from the table

the main variable coefficients changed from $p<0.05$ to $p<0.001$. Second, as shown in Table 4, I checked the robustness of individual-level estimates by running regressions for each ESS wave. All individual-level estimates in the year-specific regressions were consistent with the main pooled OLS results. Full results including all the control variables are available upon request.

\section{Conclusions and discussion}

This research explored the correlations between micro-macro-economic conditions and social cohesion attitudes through a pooled OLS approach. At the individual level, the findings in this study provide empirical support for the association between economic strain and social cohesion attitudes, contributing to several existing theories: strain is associated with lower social trust (reference group, risk aversion, and resource approaches), while it is associated with stronger egalitarian (selfinterest theory) and anti-immigration attitudes (labor market competition and group conflict theories).

Regarding the social capital dimension, the less trusting behavior of strained individuals can be linked to their risk-averse tendency. Fearing the possibility of unreciprocated trust, which can have a consequential impact on those lacking resources, strained people may choose not to trust others as a way of avoiding such risks. With lower social capital, economically disadvantaged individuals can also potentially experience a shortage in access to information or opportunities, key benefits that accrue from social capital (Adler and Kwon, 2002). Thus, strained individuals can be subject to a vicious circle of economic deprivation and social alienation (Council of Europe, 2001). Such "multiple deprivation" (Gallie et al., 2003) is discussed as detrimental to social cohesion because it can hinder community building and lead to social fragmentation.

Concerning the social order dimension, perceived threat from competition with immigrants can be a key underlying factor for economically disadvantaged people's 
greater opposition to immigration. In particular, a notable share of recent migrants to France have low levels of education and skills. Thus, economically vulnerable individuals with similar socioeconomic profiles, who tend to be in direct competition with immigrants for jobs and welfare provision, can perceive such threats more acutely. The generally lower tolerance of the economically disadvantaged toward immigrants can pose challenges to societal cohesion by hindering interethnic cooperation-an essential element of social order in present-day Europe (Kearns and Forrest, 2000: 998). Furthermore, anti-immigration attitudes motivated by economic concerns can intensify selective solidarity such as welfare chauvinism and potentially increase support for radical political parties promoting conflictual agendas (Magni, 2021).

Cross-level interactions revealed significant associations between micro-macroeconomic conditions and social cohesion attitudes. As hypothesized, macroeconomic downturns tend to intensify the egalitarian and anti-immigrant propensities of strained individuals. Individuals who perceive themselves as having low economic status are more vigilant about threats and more vulnerable and less resilient to stressors (Cohen et al., 2008; Manstead, 2018: 273). Hence, under macroeconomic stress conditions, economically disadvantaged individuals' sense of financial insecurity and concerns about employment can be exacerbated, especially given their limited material and psychological resources (Manstead, 2018). Such concerns could increase threat perception and opposition to immigration and fuel demands for egalitarian measures.

These results suggest that resentment toward out-groups, which has increasingly raised concerns in France against the backdrop of economic slowdown (Teyssedre and Le Bouler, 2019), may have been more broadly present among the lower economic strata. In fact, IFOP (2019) survey results show growing support from the underclass for the far-right nationalist party RN (Rassemblement National), which favors restrictive immigration policies. Additionally, wide gaps in immigration attitudes have been observed across political parties with distinct socioeconomic compositions of supporters. While $88 \%$ of RN supporters, mainly composed of lowincome, less educated strata, hold negative views on immigration, such views are held by only $36 \%$ of MD (Mouvement Démocrate) supporters, mostly composed of the upper-middle and wealthiest classes (IFOP, 2018, 2019).

Cross-level interactions also suggest that the wealthiest individuals' degree of support for equality and immigration can fluctuate according to changes in macroeconomic conditions. More specifically, these individuals tend to show lower support for equality under macroeconomic downturns. In such contexts, a rise in social expenditure costs can be expected, for example given the higher needs for social protection (OECD, 2012). Such expectations can induce the wealthiest individuals, who are the main contributors to state welfare, to become less willing to support egalitarian redistributive policies.

Regarding immigration attitudes, the wealthiest individuals tend to show slightly higher opposition to immigration at lower unemployment levels and lower opposition at higher unemployment levels. The relative gratification perspective offers a possible explanation for this result. Studies adopting this perspective have found that higher-status groups tend to display more negative attitudes toward immigrants 
when their relatively gratified status is perceived to be threatened or when class boundaries appear permeable (Jetten, 2019; Jetten et al., 2015; Jetten et al., 2021). For example, more favorable macroeconomic conditions such as low unemployment can be conducive to upward social mobility (Wolbers, 2008) and potentially stir concerns among the wealthiest people about losing their relatively advantaged status or distinctiveness between wealth groups. Hence, in such contexts, they may exhibit relatively higher levels of resentment toward those who appear to be challenging the status quo, such as immigrants (Jetten et al., 2015, 2021).

One important implication of the cross-level interaction is that in a period of economic contraction, attitudinal gaps between affluent and economically disadvantaged people can widen in their views of immigration and redistribution. Larger variations in the opinions on such contentious issues that constitute major political cleavages in France today (Ipsos, 2018) can present a risk for social cohesion, especially its common values dimension. Value consensus is "a basis for social order" (Schwartz and Sagie, 2000: 466), and decreasing convergence across groups against the backdrop of economic downturn can also negatively influence the social order dimension. Notably, sociopolitical tensions can intensify, and society can be more prone to conflicts. In addition, growing perceptions of a class divide and conflicts could be an obstacle to cooperation and collective action, deepen social fractures, and even trigger social unrest (Marc et al., 2013). Moreover, disparate expectations about social equality across income levels may hamper effective welfare policy implementation, leaving inequality problems insufficiently addressed, which is detrimental to societal cohesion.

These findings provide possible explanations for the recent Yellow Vest movement. Consistent with the cross-level interaction result regarding support for equality, the movement has in part been fueled by demands for greater redistribution among the vulnerable strata, who have increasingly perceived themselves as victims of relative deprivation and economic insecurity (Jetten et al., 2020). Increasingly precarious labor market conditions, polarized between insecure jobs and stable highvalue-added positions, appear to have contributed to such perceptions. Indeed, during the movement, adherents largely consisting of lower, less educated strata with lower-quality jobs called on the government to address deepening problems of inequality (Lorriaux, 2018; Teyssedre and Le Bouler, 2019: 33).

As an instance of social unrest, the movement epitomized the deepening divide and tensions between socioeconomic classes under macroeconomic pressure (Jetten et al., 2020). In particular, in line with this study's findings, the movement revealed the extent to which people in different economic circumstances held diverging opinions on taxation and redistribution and the difficulty in achieving social consensus, especially in times of economic uncertainty. Overall, by heightening the salience of tensions and conflict between socioeconomic groups, the movement posed challenges to the societal cohesion of France. 


\section{Implications}

The findings of this study imply that economic strain can negatively influence social cohesion by reducing social trust and intergroup tolerance. The empirical results also showed that the interaction between macroeconomic pressure and individual economic conditions could pose a challenge to the common values and social order dimensions. In terms of policy, the results indicate a need to address individuals' perception of economic insecurity as a way to improve social cohesion in the longterm, especially in this era of growing uncertainties.

Enhancing the economic security of vulnerable people via the provision of less precarious employment opportunities could be particularly valuable. Over the last decade, the French labor market has become more precarious and polarized. For example, from 2007 to 2017, the proportion of new recruits in CDD (fixed-term contracts) increased by approximately 10 percentage points, while the average duration of CDD decreased by half. The proportions of CDD and CDI (permanent contracts) largely vary across sectors and socioprofessional categories, and serious inequalities exist in terms of job security (Direction de l'Animation de la Recherche, des Études et des Statistiques [DARES], 2018: 1-5). Such structural conditions could intensify uncertainty about the future and vigilance to threats among the vulnerable strata, potentially negatively affecting social cohesion at the individual and societal levels.

The multiple deprivations suggested by the negative correlation of strain with social capital indicate the need for a comprehensive policy strategy. Recently, at local, national, and international levels, efforts have been made to create virtuous cycles of social cohesion by utilizing social capital as a tool for reducing economic marginalization (Daly and Silver, 2008). For example, France's politique de la ville (city policy) engages civil society actors in the decision-making and implementation of local revitalization projects, with a view to improving peri-urban problems. Such initiatives can help develop locally informed policies to address economic exclusion and simultaneously promote solidarity and cooperation beyond boundaries.

The study also suggests a need to prioritize education in social cohesion policies. Independent of the level of economic strain, education was found to be associated with higher social trust and less negative attitudes toward immigration. In fact, education has been known to cultivate social capital and inculcate civic values and norms (Huang et al., 2009). With a focus on vulnerable populations, reducing school drop-out rates or providing wider lifelong education opportunities could help foster attitudes favorable to social cohesion.

\section{Limitations and future directions}

There are some limitations of this study that future research could address. For a more robust investigation of the association between macroeconomic conditions and social cohesion attitudes, analysis of survey data with a longer time scale is necessary. This study analyzed six rounds of ESS data partly due to limitations in the early datasets. Examining macroeconomic factors using more numerous rounds 
of survey data may reveal their significant independent effects on social cohesion, which could not be fully explored in this study.

Additionally, future empirical studies should explore how economic conditions affect different forms of social capital. The literature suggests that economically deprived individuals tend to rely on bonding social networks, which help them "get by" in their daily lives, whereas they have less access to bridging social networks, which are known to be important for combatting economic exclusion (Briggs, 1998; Putnam, 1998; Warren et al., 2001). Future research can take up the challenge by using appropriate datasets that provide measures for different forms of social capital.

\section{Notes}

1. The score is the weighted mean of the item "Generally speaking, would you say that most people can be trusted or that you can't be too careful in dealing with people?" from ESS round 9. Higher scores indicate higher social trust (Netherlands: 6.13, Ireland: 5.50, United Kingdom: 5.19, Belgium: 5.11, Switzerland: 5.90, Germany: 5.28, Spain: 5.11, Italy: 4.76).

2. Using the reverse-coded 5-point scale item "the government should take measures to reduce differences in income levels" of ESS round 9, each country's weighted mean score of egalitarian attitude was calculated. France was the 8th highest (4.08) among 27 countries.

\section{References}

Adler, P.S., and S.-W. Kwon. 2002. Social capital: Prospects for a new concept. The Academy of Management Review 27 (1): 17-40.

American Psychological Association. 2009. What the economic downturn means for children, youth and families. https://www.apa.org/pi/families/resources/economy.aspx. Accessed 20 Sep 2020.

Ananyev, M., and S. Guriev. 2018. Effect of income on trust: evidence from the 2009 economic crisis in Russia (EBRD Paper No. 209). European Bank for Reconstruction and Development.

Andreß, H.-J., D. Fetchenhauer, and H. Meulemann. 2019. Cross-national comparative research-analytical strategies, results, and explanations. KZfSS Kölner Zeitschrift Für Soziologie Und Sozialpsychologie 71: 1-28.

Andrews, R., S. Jilke, and S. Van de Walle. 2014. Economic strain and perceptions of social cohesion in Europe: Does institutional trust matter? European Journal of Political Research 53 (3): 559-579.

Bailey, N., A. Kearns, and M. Livingston. 2012. Place attachment in deprived neighbourhoods: The impacts of population turnover and social mix. Housing Studies 27 (2): 208-231.

Baslevent, C., and H. Kirmanoglu. 2011. Discerning self-interested behaviour in attitudes towards welfare state responsibilities across Europe. International Journal of Social Welfare 20 (4): 344-352.

Bell, A., M. Fairbrother, and K. Jones. 2019. Fixed and random effects models: Making an informed choice. Quality \& Quantity 53 (2): 1051-1074.

Bennett, J., and K. Möhring. 2015. Cumulative (dis)advantage? The impact of labour market policies on late career employment from a life course perspective. Journal of Social Policy 44 (2): 213-233. 
Berger-Schmitt, R. 2000. Social Cohesion as an Aspect of the Quality of Societies: Concept and Measurement (EuReporting Working Paper No. 14). Mannheim: Centre for Survey Research and Methodology (ZUMA), Social Indicators Department.

Berkman, L.F., and S.L. Syme. 1979. Social networks, host resistance, and mortality: A nine-year followup study of Alameda County residents. American Journal of Epidemiology 109 (2): 186-204.

Billiet, J., B. Meuleman, and H. De Witte. 2014. The relationship between ethnic threat and economic insecurity in times of economic crisis: Analysis of European Social Survey data. Migration Studies 2 (2): 135-161.

Blekesaune, M. 2007. Economic conditions and public attitudes to welfare policies. European Sociological Review 23 (3): 393-403.

Boisnault, D., P. Leblanc, and G. Lefebvre. 2011. Vue d'ensemble - L'économie française sort de récession. L'économie française, édition 2011. Paris: Institut National de la Statistique et des Etudes Economiques.

Brady, H., S. Verba, and K. Schlozman. 1995. Beyond SES: A resource model of political participation. American Political Science Review 89 (2): 271-294.

Branscombe, N.R., M.T. Schmitt, and R.D. Harvey. 1999. Perceiving pervasive discrimination among African Americans: Implications for group identification and well-being. Journal of Personality and Social Psychology 77 (1): 135-149.

Briggs, X.S. 1998. Brown kids in white suburbs: Housing mobility and the many faces of social capital. Housing Policy Debate 9 (1): 177-221.

Busemeyer, M.R., and E. Neimanns. 2017. Conflictive preferences towards social investments and transfers in mature welfare states: The cases of unemployment benefits and childcare provision. Journal of European Social Policy 27 (3): 229-246.

Callen, T. 2008. What is Gross Domestic Product? Finance \& Development, International Monetary Fund 45 (4): 48-49.

Cameron, A.C., and D.L. Miller. 2015. A practitioner's guide to cluster-robust inference. Journal of Human Resources 50 (2): 317-372.

Cameron, A.C., J.B. Gelbach, and D.L. Miller. 2008. Bootstrap-based improvements for inference with clustered errors. The Review of Economics and Statistics 90 (3): 414-427.

Ceobanu, A.M., and X. Escandell. 2010. Comparative analyses of public attitudes toward immigrants and immigration using multinational survey data: A review of theories and research. Annual Review of Sociology 36: 309-328.

Chen, M.-H. 2010. The economy, tourism growth and corporate performance in the Taiwanese hotel industry. Tourism Management 31: 665-675.

Cohen, S., C.M. Alper, W.J. Doyle, N. Adler, J.J. Treanor, and R.B. Turner. 2008. Objective and subjective socioeconomic status and susceptibility to the common cold. Health Psychology 27 (2): 268-274.

Collier, P. 1999. On the economic consequences of civil war. Oxford Economic Papers 51 (1): 168-183.

Commissariat Général à l'Egalité des Territoires. 2018. Rapport sur la cohésion des territoires. Paris: CGET

Council of Europe. 2001. Promoting the policy debate on social exclusion from a comparative perspective. Trends in Social Cohesion 1. Germany: CoE.

Dahrendorf, R., F. Field, C. Hayman, and I. Hutcheson. 1995. Report on wealth creation and social cohesion in a free society. London: Commission on Wealth Creation and Social Cohesion.

Daly, M., and H. Silver. 2008. Social exclusion and social capital: A comparison and critique. Theory and Society 37 (6): 537-566.

Davidov, E., and B. Meuleman. 2012. Explaining attitudes towards immigration policies in European countries: The role of human values. Journal of Ethnic and Migration Studies 38 (5): 757-775.

de Melo, M., C. Denizer, and A. Gelb. 1996. Patterns of transition from plan to market. The World Bank Economic Review 10 (3): 397-424.

Delhey, J., and K. Newton. 2003. Who trusts?: The origins of social trust in seven societies. European Societies 5 (2): 93-137.

Dinesen, P.T. 2013. Where you come from or where you live? Examining the cultural and institutional explanation of generalized trust using migration as a natural experiment. European Sociological Review 29 (1): 114-128.

Direction de la Recherche, des Etudes, de l'Evaluation et des Statistiques. 2020. Le Baromètre d'opinion de la DREES data. Paris: DREES, Ministère des Solidarités et de la Santé. http://www.data.drees. sante.gouv.fr/ReportFolders/reportFolders.aspx. Accessed 15 Sep 2020. 
des Études et des Statistiques. 2018. CDD, CDI : comment évoluent les embauches et les ruptures depuis 25 ans? DARES analyses 26. Paris: DARES

Direction Générale de la Cohésion Sociale. 2017. Baromètre de perception de la cohésion sociale 2016 de la DGCS. Les Notes de la Mission Analyse Stratégique, Synthèses et Prospective 36. Paris: DGCS.

Domergue, F. 2012. Diplômes et formations professionnelles des nouveaux migrants. Infos migrations 37. Paris: Département des Statistiques, des Etudes et de la Documentation.

Dotti Sani, G.M., and B. Magistro. 2016. Increasingly unequal? The economic crisis, social inequalities and trust in the European Parliament in 20 European countries. European Journal of Political Research 55 (2): 246-264.

Dubet, F. 2014. La Préférence pour l'inégalité. Comprendre la crise des solidarités. Paris: Seuil.

Economou, M., M. Madianos, L.E. Peppou, K. Souliotis, A. Patelakis, and C. Stefanis. 2014. Cognitive social capital and mental illness during economic crisis: A nationwide population-based study in Greece. Social Science \& Medicine 100: 141-147.

Esarey, J., and A. Menger. 2019. Practical and effective approaches to dealing with clustered data. Political Science Research and Methods 7 (3): 541-559.

European Social Survey. 2018. ESS Round 9: European Social Survey Round 9 Data. Oslo: Norwegian Centre for Research Data.

Fairbrother, M., and I.W. Martin. 2013. Does inequality erode social trust? Results from multilevel models of US states and counties. Social Science Research 42 (2): 347-360.

Fisman, R., P. Jakiela, and S. Kariv. 2014. How did distributional preferences change during the Great Recession? (NBER Working Paper No. 20146). Cambridge, MA: National Bureau of Economic Research.

Fjær, E.L., P. Stornes, L.V. Borisova, C.L. McNamara, and T.A. Eikemo. 2017. Subjective perceptions of unmet need for health care in Europe among social groups: Findings from the European social survey (2014) special module on the social determinants of health. European Journal of Public Health 27: 82-89.

Fried, Y., A.S. Levi, S.W. Billings, and K.R. Browne. 2001. The relation between political ideology and attitudes toward affirmative action among African-Americans: The moderating effect of racial discrimination in the workplace. Human Relations 54 (5): 561-584.

Gallie, D., S. Paugam, and S. Jacobs. 2003. Unemployment, poverty and social isolation: Is there a vicious circle of social exclusion? European Societies 5 (1): 1-32.

Glei, D.A., N. Goldman, and M. Weinstein. 2018. Perception has its own reality: Subjective versus objective measures of economic distress. Population and Development Review 44 (4): 695-722.

Green, E.G.T., N. Fasel, and O. Sarrasin. 2010. The more the merrier? The effects of type of cultural diversity on exclusionary immigration attitudes in Switzerland. International Journal of Conflict and Violence 4 (2): 177-190.

Green, A., J. Preston, and R. Sabates. 2003. Education, Equality, and Social Cohesion A distributional approach. Compare A Journal of Comparative and International Education 33 (4): 453-470.

Hasenfeld, Y., and J.A. Rafferty. 1989. The determinants of public attitudes toward the welfare state. Social Forces 67 (4): 1027-1048.

Helliwell, J., and R. Putnam. 1995. Economic growth and social capital in Italy. Eastern Economic Journal 21 (3): 295-307.

Herzog, L. 2018. Durkheim on social justice: The argument from "organic solidarity." American Political Science Review 112 (1): 112-124.

Heyer, E., and X. Timbeau. 2017. France : Croissance en héritage. Perspectives 2017-2019 pour l'économie française. Revue De l'OFCE, Presses De Sciences-Po 152: 129-213.

Hierro, M.J., and G. Rico. 2019. Economic crisis and national attitudes: Experimental evidence from Spain. Ethnic and Racial Studies 42 (5): 820-837.

Huang, J., H.M. van den Brink, and W. Groot. 2009. A meta-analysis of the effect of education on social capital. Economics of Education Review 28 (4): 454-464.

IFOP. 2018. Le regard des Français sur l'immigration. https://jean-jaures.org/nos-productions/leregard-des-francais-sur-1-immigration-0. Accessed 10 Sep 2020.

IFOP. 2019. Européennes 2019 : profil des électeurs et clefs du scrutin. https://www.ifop.com/publi cation/europeennes-2019-profil-des-electeurs-et-clefs-du-scrutin/. Accessed 10 Sep 2020.

Ipsos. 2018. Les nouveaux enjeux de la République. https://www.ipsos.com/fr-fr/les-nouveauxenjeux-de-la-republique-27eme-journee-du-prix-du-livre-politique. Accessed $20 \mathrm{Sep} 2020$.

Janmaat, J.G. 2011. Social cohesion as a real-life phenomenon: Assessing the explanatory power of the universalist and particularist perspectives. Social Indicators Research 100 (1): 61-83. 
Jæger, M.M. 2006. What makes people support public responsibility for welfare provision: Self-interest or political ideology? Acta Sociologica 49 (3): 321-338.

Jenson, J. 2010. Defining and Measuring Social Cohesion. London: Commonwealth Secretariat and United Nations Research Institute for Social Development.

Jetten, J. 2019. The wealth paradox: Prosperity and opposition to immigration. European Journal of Social Psychology 49 (6): 1097-1113.

Jetten, J., F. Mols, and H.P. Selvanathan. 2020. How economic inequality fuels the rise and persistence of the Yellow Vest movement. International Review of Social Psychology 33 (1): 1-12.

Jetten, J., F. Mols, and N.K. Steffens. 2021. Prosperous but fearful of falling: The wealth paradox, collective angst, and opposition to immigration. Personality and Social Psychology Bulletin 47 (5): 766-780.

Jetten, J., F. Mols, and T. Postmes. 2015. Relative deprivation and relative wealth enhances antiimmigrant sentiments: The v-curve re-examined. PLoS ONE 10 (10): e0139156.

Kawachi, I., and B.P. Kennedy. 1997. Health and social cohesion: Why care about income inequality? British Medical Journal 314: 1037-1040.

Kearns, Ade, and Ray Forrest. 2000. Social Cohesion and Multilevel Urban Governance. Urban Studies 37 (5-6): 995-1017.

Kehrberg, J. 2007. Public opinion on immigration in Western Europe: Economics, tolerance, and exposure. Comparative European Politics 5: 264-281.

Keller, D., and P. Lafont. 2020. Se donner un nouveau cap - Rapport annuel sur l'état de la France 2019. Avis du Conseil économique, social et environnemental. Paris: CESE.

Kesler, C., and I. Bloemraad. 2010. Does immigration erode social capital? The conditional effects of immigration-generated diversity on trust, membership, and participation across 19 countries, 1981-2000. Canadian Journal of Political Science 43 (2): 319-347.

Kraus, M.W., P.K. Piff, and D. Keltner. 2011. Social class as culture: The convergence of resources and rank in the social realm. Current Directions in Psychological Science 20 (4): 246-250.

Kraus, M.W., P.K. Piff, R. Mendoza-Denton, M.L. Rheinschmidt, and D. Keltner. 2012. Social class, solipsism, and contextualism: How the rich are different from the poor. Psychological Review 119 (3): 546-572.

Kronauer, M. 1998. Social exclusion and underclass-new concepts for the analysis of poverty. In Empirical Poverty Research in a Comparative Perspective, ed. A. Hans-Jurgen, 51-75. Aldershot: Ashgate.

Lancee, B., and S. Pardos-Prado. 2013. Group conflict theory in a longitudinal perspective: Analyzing the dynamic side of ethnic competition. International Migration Review 47 (1): 106-131.

Lorriaux, A. 2018. Ce que révèlent les sondages sur l'identité des «gilets jaunes». Slate, December 4. http://www.slate.fr/story/170766/qui-sont-gilets-jaunes-et-soutiens-portrait-robot-categoriessocio-professionnelles. Accessed 27 June 2021.

Magni, G. 2021. Economic inequality, immigrants and selective solidarity: from perceived lack of opportunity to in-group favoritism. British Journal of Political Science 51 (4): 1357-1380.

Malhotra, N., Y. Margalit, and C.H. Mo. 2013. Economic explanations for opposition to immigration: Distinguishing between prevalence and conditional impact. American Journal of Political Science 57 (2): 391-410.

Manstead, A.S.R. 2018. The psychology of social class: How socioeconomic status impacts thought, feelings, and behaviour. British Journal of Social Psychology 57 (2): 267-291.

Marc, A., A. Willman, G. Aslam, M. Rebosio, and K. Balasuriya. 2013. Societal dynamics and fragility: Engaging societies in responding to fragile situations New frontiers of social policy. Washington, DC: World Bank.

Merton, R.K., and A.S. Kitt. 1950. Contributions to the theory of reference group behavior. In Continuities in Social Research: Studies in the Scope and Method of "The American Soldier", ed. R.K. Merton and P.F. Lazarfeld, 40-105. Glencoe, Illinois: The Free Press.

Möhring, K. 2012. The fixed effects approach as alternative to multilevel models for cross-national analyses (GK SOCLIFE Working Paper Series WP 16/2012). Cologne: University of Cologne.

OECD. 2012. Social spending during the crisis: Social Expenditure (SOCX) data update 2012. Paris: OECD.

OECD. 2020. Unemployment rate (indicator). https://doi.org/10.1787/52570002-en. Accessed 23 July 2020.

Paxton, P. 2002. Social capital and democracy: An interdependent relationship. American Sociological Review 67 (2): 254-277.

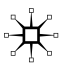


Portela, M., I. Neira, and M. Salinas-Jiménez. 2013. Social capital and subjective wellbeing in Europe: A new approach on social capital. Social Indicators Research 114: 493-511.

Putnam, R.D. 1998. Foreword. Housing Policy Debate 9 (1): 5-8.

Putnam, R.D. 2001. Bowling Alone: The Collapse and Revival of American Community. New York, NY: Simon \& Schuster.

Reeskens, T., and W. van Oorschot. 2015. Immigrants' attitudes towards welfare redistribution An exploration of role of government preferences among immigrants and natives across 18 European welfare states. European Sociological Review 31 (4): 1-13.

Rosenfeld, R., and R. Fornango. 2007. The impact of economic conditions on robbery and property crime: The role of consumer sentiment. Criminology an Interdisciplinary Journal 45 (4): $735-769$.

Rosset, J., and J. Pontusson. 2014. The impact of the Great Recession on public preferences for redistribution in Western Europe. Paper prepared for presentation at the Annual Meeting of the American Political Science Association, Washington, D.C., August 29, 2014.

Rothstein, B., and D. Stolle. 2003. Social capital, impartiality and the welfare state: An institutional approach. In Generating Social Capital, ed. M. Hooghe and D. Stolle, 191-209. New York, NY: Palgrave Macmillan.

Rueda, D., and D. Stegmueller. 2016. The externalities of inequality: Fear of crime and preferences for redistribution in Western Europe. American Journal of Political Science 60 (2): 472-489.

Sagiv, L., S. Roccas, and O. Hazan. 2012. Value pathways to well-being: Healthy values, valued goal attainment, and environmental congruence. In Positive Psychology in Practice, ed. P.A. Linley and S. Joseph, 68-85. Hoboken, New Jersey: John Wiley \& Sons Inc.

Scheve, K.F., and M.J. Slaughter. 2001. Labor market competition and individual preferences over immigration policy. The Review of Economics and Statistics 83 (1): 133-145.

Schlozman, K., S. Verba, and H. Brady. 1999. Civic participation and the equality problem. In Civic Engagement in American Democracy, ed. T. Skocpol and M. Fiorina, 427-460. Washington, D.C.: Brookings Institution Press.

Schmeets, H., and S. te Riele. 2014. Declining social cohesion in the Netherlands? Social Indicators Research 115: 791-812.

Schwartz, S.H., and G. Sagie. 2000. Value consensus and importance: A cross-national study. Journal of Cross-Cultural Psychology 31 (4): 465-497.

Semyonov, M., R. Raijman, and A. Gorodzeisky. 2006. The rise of anti-foreigner sentiment in European societies, 1988-2000. American Sociological Review 71 (3): 426-449.

SES-ENS. 2018. Les sciences sociales et le mouvement des "gilets jaunes". Novembre-décembre 2018. http://ses.ens-lyon.fr/actualites/rapports-etudes-et-4-pages/les-sciences-sociales-et-lemouvement-des-gilets-jaunes.

Sihvo, T., and H. Uusitalo. 1995. Economic crises and support for the welfare state in Finland 19751993. Acta Sociologica 38 (3): 251-262.

Stanley, D. 2003. What do we know about social cohesion: The research perspective of the federal government's social cohesion research network. Canadian Journal of Sociology 28 (1): 5-17.

Szczepanski, M. 2019. A decade on from the crisis: Main responses and remaining challenges. Brussels: European Parliamentary Research Service.

Teyssedre, C., and H. Le Bouler. 2019. Cohésion et transitions : agir autrement-Rapport annuel sur l'état de la France 2019. Avis du Conseil économique, social et environnemental. Paris: CESE.

The World Bank. 2020. GDP growth. https://data.worldbank.org/share/widget?indicators=NY.GDP. MKTP.KD.ZG\&locations=FR

Uslaner, E.M. 2000. Producing and consuming trust. Political Science Quarterly 115 (4): 569-590.

Uslaner, E.M., and M. Brown. 2005. Inequality, trust, and civic engagement. American Politics Research 33 (6): 868-894.

Van Oorschot, W. 2002. Individual motives for contributing to welfare benefits in the Netherlands. Policy and Politics 30 (1): 31-46.

Vergolini, L. 2011. Social cohesion in Europe: How do the different dimensions of inequality affect social cohesion? International Journal of Comparative Sociology 52 (3): 197-214.

Verkuyten, M., and K. Yogeeswaran. 2017. The social psychology of intergroup toleration: A roadmap for theory and research. Personality and Social Psychology Review 21 (1): 72-96.

Warren, M.R., P.J. Thompson, and S. Saegert. 2001. The role of social capital in combating poverty. In Social Capital and Poor Communities, ed. S. Saegert, P.J. Thompson, and M.R. Warren, 1-28. New York: Russell Sage Foundation Press. 
Wilkinson, R., and K. Pickett. 2009. The Spirit Level: Why Greater Equality Makes Societies Stronger. New York: New York Bloomsbury Press.

Wolbers, M. H. J. 2008 Increasing labor market instability among young people? Labor market entry and early career development among school-leavers in the Netherlands since the mid-1980s. In: H-P. Blossfeld, S. Bucholz, E. Bukodi, and K. Kurz (eds) Young Workers Globalization and the Labor Market Comparing Early Working Life in Eleven Countries. Edward Elgar, Cheltenham, pp. 77-101

Yan, Z., and B. Lin. 2020. WCBREGRESS: Stata module to estimate a linear regression model with clustered errors using the wild cluster bootstrap standard errors. Statistical Software Components S458863, Boston College Department of Economics. https://ideas.repec.org/c/boc/bocode/s458863.html.

Publisher's Note Springer Nature remains neutral with regard to jurisdictional claims in published maps and institutional affiliations. 